\title{
Güzel Sanatlar Lisesi Öğrencilerinin Optimal Performans Duygu Durumlarının Çeşitli Değişkenler Açısından İncelenmesi*
}

\section{Serkan UMUZDAŞ ${ }^{* *}$, Özgür KOÇAK ${ }^{* * *}$, Serpil UMUZDAŞ ${ }^{* * * *}$}

Öz: Bu araştırma Güzel Sanatlar Lisesi öğrencilerinin optimal performans duygu durumlarına etki eden çeşitli değişkenleri incelemeyi amaçlamaktadır. Araştırma, betimsel nitelikte ilişkisel tarama modeli esas alınarak yapılmıştır. Araştırmaya katılan öğrencilerin, optimal performans duygu durumlarına etki eden çeşitli değişkenler incelenmiştir. Araştırmanın ölçekleri 2018-2019 eğitim-öğretim yılında uygulanmış olup, örneklemini Orta Karadeniz Bölgesinde (Amasya, Çorum, Ordu, Samsun, Tokat) bulunan Güzel Sanatlar Lisesinde müzik eğitimi alan 9, 10, 11 ve 12.sınıf 189 kadın 111 erkek toplam 300 öğrenci oluşturmaktadır. Veri toplama aracı olarak, öğrencilerin demografik özellikleriyle ilgili bilgi elde etmek amacıyla "Kişisel Bilgi Formu” kullanılmıştır. Kişilik özelliklerini ölçmek için "Rammstedt ve John (2007) tarafından geliştirilen, Horzum ve diğ. (2017) tarafından Türkçeye uyarlanan, 5'i olumsuz 5'i olumlu toplam 10 madde ve 5 boyuttan oluşan "Beş Faktör Kişilik Ölçeği”" ve optimal performans duygu durumlarını ölçmek için ise Jackson ve Eklund (2002) tarafından geliştirilen ve Aşçı ve diğ. (2007) tarafından Türkçe'ye uyarlanarak, geçerlik ve güvenirlik çalışması yapılan 36 madde ve dokuz faktörden/boyuttan oluşan Durumluk ve Sürekli Optimal Performans Duygu Durum Ölçeği-2 (SOPDDÖ-2) kullanılmıştır. Araştırmada elde edilen bulgularda öğrencilerin, optimal performans duygu durum düzeyi ile cinsiyet, sınıf seviyesi, bireysel çalgı türü, bireysel çalg1 çalma süreleri (yıl), bireysel çalgılarıyla haftalık yaptıkları egzersiz sayıları, bireysel çalgılarıyla katıldıkları etkinlik düzeyi ve kişilik özellikleri arasındaki ilişki incelenmiş; değişkenler arasında genel ve alt boyutsal olarak

\footnotetext{
*Bu çalışma ikinci yazarın "Güzel sanatlar lisesi öğrencilerinin bireysel çalgı performanslarına yönelik optimal performans duygu durumlarının çeşitli değişkenler açısından incelenmesi (Orta Karadeniz bölgesi örneği)" adlı Yüksek lisan tezinin bir parçasıdır.

**Doç. Dr., Tokat Gaziosmanpaşa Üniversitesi, Devlet Konservatuvarı, Email: sumuzdas@yahoo.com Orcid No: 0000-0002-5455-2770

*** Müzik Öğretmeni, Email: asicello@hotmail.com Orcid No: 0000-0002-9131-160X

****Doç. Dr., Tokat Gaziosmanpaşa Üniversitesi, Devlet Konservatuvarı, Email: sumuzdas@hotmail.com, Orcid No: 00000002-6013-2406
} 
anlamlı farklılıklar gözlenmiş ve elde edilen sonuçlara dayanarak çeşitli önerilerde bulunulmuştur.

Anahtar Kelimeler: Çalgı Eğitimi, Optimal Performans Duygu Durumu, Beş Faktör Kişilik Özellikleri.

\title{
Investigation Of The Flow State of Fine Arts High School Students' In Terms of Various Varieties
}

\begin{abstract}
This research aimed to investigate the various varieties that effects of the flow state of Fine Art High School students' instrument performance. The research is based on a descriptive correlational survey model. Various variables that affect the optimal performance of the instrument performance of the students who participated in the study were examined. The scales of the study were applied in 2018-2019 academic year and sampled in Fine Arts High Schools that located in Middle Black Sea Region (Amasya, Çorum, Ordu, Samsun, Tokat) with 9, 10, 11 and 12th grade 189 female 111 male total 300 students who are registered in the department of music. "Personal Information Form” used as a data collecting tool to obtain information about the demographic feature of the students. "Five Factor Personality Inventory” which has 10 questions (5 positives, 5 negative) and 5 factors, developed by Rammstedt and John (2007), and translated in Turkish by Horzum, Ayas, and Padir (2017) were used to survey the personality features. To survey the flow state, Dispositional Flow Scale-2 (DFS-2) and Flow State Scale-2 (FSS-2) which has 36 questions and nine factors, developed by Jackson and Eklund (2002), and adapted into Turkish as validated and reliable by Aşçı, Çağlar, Eklund, Altınbaş, and Jackson (2007), was used. According to results of the study, the correlation between students' flow state, and gender, class level, instrument type, instrument playing time (year), amount of weekly exercises with the instrument, level of events they attend with their instruments and personality features was examined, significant differentiation between the varieties in general and sub dimensional was observed, and various suggestions were made based on the results obtained.
\end{abstract}

Keywords: Instrument Education, Flow State, Five Factor Personality Inventory

\section{Giriş}

Antik Yunan Filozoflarından Aristoteles 2300 yıl önce, tüm insanların her şeyden önce mutluluğu aradıkları sonucuna ulaşmış ve kişiyi mutluluğa ulaştıracak unsurlardan birinin de eğitim olduğunu vurgulamıştır. O’na göre insan, akıllı bir varlıktır ve aklın ilkelerine uygun 
olarak yaşamalıdır. Eğitim yolu ile ussal melekelerini geliştiren insan; etik ve siyasal davranışlarını belirleyecek, en iyiye, en mükemmele yani mutlu bir yaşama ulaşması beklenir (Y1lmaz, 2004).

Türk Dil Kurumu, mutluluğu; "Bütün özlemlere eksiksiz ve sürekli olarak ulaşılmaktan duyulan kıvanç durumu, mut (I), ongunluk, kut, saadet, bahtiyarlık, saadetlilik” olarak tanımlamaktadır (Türk Dil Kurumu, 2011). Mutluluk ve eğitim, korelasyonel biçimde sosyal ve beşeri bilimlerin ilgi konusu olmuştur.

Akla sahip bir canlı türü olarak insan, kendi gelişimi için gereksinimlerini tespit etmeli ve gerek duyduklarına sahip olmak için sorumluluk almalıdır. Bu durum onu sorgulamaya ve bilgi toplamaya yöneltir. Bu motivasyon, insanın eğitim ihtiyacının temelini oluşturmaktadır.

Yılmaz (2004) güncel eğitim anlayışında, ussal melekeleri ile yapacakları tercihlerinde ne istediğinin farkında, sosyal düzen içinde sahiplenecekleri amaç ve roller vasıtasıyla öz kimliklerini belirleyebilen birey modelini öne çıktığından bahseder. Bireyler bu düşünceyle yetiştiklerinde, kendini ifade edebilen, geleceğe dair güven içinde, mutlu bireyler olarak görülmektedirler.

Bireylere ve toplumlara şekil verme, onları yönlendirip değiştirme ve geliştirmede en etkili yöntem eğitimdir. En genel tanımını yapan Ertürk (1997)'e göre eğitim bireyin herhangi bir davranışında, kendi yaşantıları aracılığıyla, kasıtlı ve istendik değişim oluşturma süreci olarak tanımlanmaktadır. Sönmez (1986) bu tanımdaki istendik davranışların öğrenme süreci ile bireye kazandırıldığını ifade etmektedir.

İnsan; bilişsel, duyuşsal, devinişsel ve algısal olarak doğuştan birtakım özelliklerle vardır. Doğuştan getirdiği bu gizil-güçleri eğitim yolu ile geliştirebilmektedir. Zira eğitimin görevlerinden biri de insanın kabiliyetlerini en üst noktaya çıkarmaktır (Sönmez, 1994).

Düşünmeyi, keşfetmeyi, iş birliği ve yardımlaşma içerisinde olmayı, yaşamdaki seçenekleri değerlendirip karar vermeyi, sorumluluk almayı, işlevli görevleri bitirebilmeyi öğrenen birey yaşamda optimum mutluluğa yönlenir. Bu beceriler bir anda olmayacağı gibi, kültürel olarak çevre değişkenlerinden etkilenir. Üst düzey beceriler olarak betimlenebilecek olan bu yetiler; günlük, basit ihtiyaçların ve faydacılığın üzerindedir. Estetik, felsefe ve sanat gibi bütüncül bakış açılarını barındırır. 
Optimal sözcüğ̈̈; en etkili, en uygun anlamını taşımaktadır. Optimal çalgı performansı için müzisyen işlevsiz şeyleri düşünmeden müziği yansıtabilmelidir. Optimal performans duygu durumu, akış deneyimi olarak betimlenebilir. İlk olarak 1975 yılında Macar Psikolog Csikszentmihalyi tarafından kaleme aldığı "Beyond Boredom and Anxiety (Sıkıntı ve Kaygının Ötesinde)" adlı kitabında ele alınmıştır. Kivikangas (2006) ve Moneta (2004) kişinin bu duygu durumunu spor, sanat ve iş gibi birçok etkinlik anında yaşayabileceğini ve yapmış olduğu görevin içinde kaybolarak, görev üzerinde kendini bilişsel olarak yeterli ve kontrollü hissetmesini, yaptığı etkinliğe dair içsel haz ve zevk duyması olarak tanımlanmaktadırlar.

Csikszentmihalyi'nin kuramının temelini oluşturan akış kavramı, kişinin yaptığı işi, herhangi bir dışsal mükafat için değil tamamen içinden gelen dürtüler ile gerçekleştirilmesini anlatmakta ve bu durum, bireyin yaptığ işten, yaşamından mutluluk ve hoşnutluk duymasını sağlamaktadır. Csikszentmihalyi 1975'ten bu zamana kadar yapmış olduğu çalışmaların temelinde akış kuramını, güdülenmeyi, kişiliği ve öznel yaşantıyı tek bir çerçevede toplamaya çalışmıştır.

Baumann (2012), bireylerin optimal performans seviyesine nasıl erişebileceklerini veya akış eğilimlerini en iyi şekilde anlamak için, ototelik (bir etkinliği gerçekleştiriyor olan kişinin enerjik bir şekilde odaklandığını, tamamen dahil olduğunu ve etkinlik süresince keyif aldığını hissederek kendini tamamen etkinliğe verdiği zamanki zihinsel durumdur) kişilik kavramını anlamanın gerektiğini vurgulamış ve bu konu üzerinde yapılan araştırmaların ototelik kişilik ve ototelik kişilikte olan bireylerin sahip olabileceği özelliklerin şifrelerini çözmeye başlamış olsa da bazılarının ne sebeple daha fazla bu özellikleri gösterdikleri hakkında yeteri kadar bilgi bulunmadığını belirtmiş, bu yönde en önemli olasılığın bireyin kişiliğini oluşturan farklı özelliklerin varlığı olduğunu ifade etmiştir. Kişilik konusuyla ilgilenen araştırmacı ve kuramcılar, kişiliği çeşitli şekillerde sınıflandırarak daha iyi anlamaya, çözümlemeye ve yorumlamaya çalışmışlardır. McCrae ve Costa (2008) dışadönüklük, yumuşak başlılık, öz-denetim, duygusal denge (nörotizm) ve deneyime açıklık olarak beş faktörle çalışmıştır.

Çağdaş sistem içinde eğitim; bilimsel, sanatsal ve teknik boyutlar ile geliştirilmektedir. Özellikle çalgı eğitimi, tüm bu boyutları barındıran, bireylerin kişilik özelliklerini dikkate alarak çalışan, bireysel bir kurumdur. Bu bağlamda müzik eğitimi, bireylerin; yaratıcı ve 
özgür düşünceler ile kendini ve çevresini daha iyi algılaması, ihtiyaçlarını fark etmesi, dengeli, duyarlı, medeni bir toplum paydaşı olmasını sağlamaktadır.

Müziği barındıran bir eğitim örüntüsünde, bireyin müzik yoluyla kendi düşüncelerini, potansiyelini, isteklerini ve yeteneklerinin farkına varması amaçlanmaktadır. Türkiye’de konservatuvarlar dışında mesleki eğitimde erken sayılabilecek yaşa yönelik müzik eğitimi verilen kuruluş; Güzel Sanatlar Lisesidir. Bu liselerde eğitim gören öğrenciler, uyum gösterdikleri çalgılar aracılığıyla müziği tanımaya çalışmaktadır. Burada çalgının, müziğin algılanmasında ve somutlaştırılmasında önemli rolü vardır.

Öğrencilerin bireysel çalgı performanslarını arttırabilmeleri ve bu performanslardan zevk, mutluluk alabilmeleri hedefi ile Güzel Sanatlar Lisesi öğrencilerinin optimal performans duygu durumlarının cinsiyet, sınıf düzeyi, bireysel çalgıları ve kişilik özellikleri ile ilgili çeşitli demografik değişkenlere göre farklılaşıp farklılaşmadığı incelenmiştir.

Optimal performans duygu durum ya da akış kavramı çerçevesinde Türkiye’de genellikle spor ve egzersiz alanındaki çalışmalara konu olmakla birlikte özellikle sanat alanında Çetinkalp (2011)' in “Optimal Performans Duygu Durumu ve Fiziksel Benlik Algısı: Dansçılar Üzerine Bir Çalışma” başlıklı yüksek lisans tez çalışması, müzik alanında ise Teztel (2016)'in “Psikolojide akış kuramı ve müzik icrası bağlamında değerlendirilmesi” başlıklı makalesi olmak üzere iki akademik çalışmaya rastlanmıştır. Bunu yanında literatürde, Bakker (2005), müzik öğretmenleri ile yaptığı çalışmada; kendisine yetki ve çalışma desteği verilen ve dönüt sağlanan öğretmenlerde akış deneyiminin doğru orantılı olarak artış gösterdiğini gözlemlemiştir. Yaşin (2016) tarafından hazırlanan "Kişilik özellikleri ve psikolojik sermayenin psikolojik iyi oluş, akış deneyimi, iş tatmini ve çalışan performansına etkileri” adlı doktora tezinde akış deneyiminin çalışan üzerinde olumlu sonuç verdiği tespit edilmiştir. Demirutku ve Ağaoğlu (2018)'nun yaptığı tiyatro izleyicisinin akış deneyimine yönelik araştırmada uyarılma aracı olarak kullanılan tiyatro oyununun akış deneyimini tetiklediği, olumludan daha fazla olumsuz duygu durum uyandıran bir oyun olduğu ve oyunu izleyen katılımcıların da duygu şiddeti temelinde oyuncuların değerlendirmelerine benzer deneyim rapor ettikleri saptanmıştır. Sahranç (2013)'ın yaptığı araştırmada ise üniversite öğrencilerinin genel öz-yeterlik algısı, durumluk kaygı, stres kontrol değerlendirmesinin ekzojen değişkenler ve yaşam doyumu aracı (mediator) değişken olarak ele alınıp akış deneyimiyle ilişkisini betimleyen bir model test edilmiştir. Sonuç olarak stresini kontrol edebilen bireylerin yaşam 
doyumlarının ve akış deneyimlerinin yüksek olduğu, yaşam doyumu yüksek öğrencilerin daha yüksek düzeyde akış deneyimi yaşadıkları, öz-yeterlik algısı yüksek öğrencilerin yaşam doyumlarının ve akış deneyimlerinin yüksek olduğu doğrulanmıştır. Eryılmaz ve Mammadov (2016) tarafından matematik dersinde akış durumu ölçeğinin geliştirilmesine yönelik yapılan araştırmada güvenirliği yüksek bir ölçek elde edilmiştir. O'Neill (1999)'ın akış deneyimi ve müzikal performans becerilerinin geliştirilmesi isimli çalışmasında ise öğrencilerin çeşitli işler üzerinde akış deneyimi ve müzik performans becerileri ölçülerek, olumlu etkisi olduğu sonucuna varılmıştır. Ayrıca Sheridan ve Byrne (2002) 'in yaptı̆̆ı araştırmada İskoç ortaöğretim müzik değerlendirme sisteminin akış deneyimine engel olabileceği tartışılmıştır.

\begin{abstract}
Alt Problemler
Araştırmanın ana problemine bağlı olarak aşağıdaki alt problemlere cevap aranmıştır. Araştırmaya katılan;
\end{abstract}

1. Güzel Sanatlar Lisesi öğrencilerinin Optimal Performans Duygu Durumlarıyla cinsiyet arasında anlamlı farklılık var mıdır?

2. Güzel Sanatlar Lisesi öğrencilerinin Optimal Performans Duygu Durumlarıyla çalgı branşları arasında anlamlı farklılık var mıdır?

3. Güzel Sanatlar Lisesi öğrencilerinin Optimal Performans Duygu Durumlarıyla bireysel çalgılarını çalma süreleri arasında anlamlı farklılık var mıdır?

4. Güzel Sanatlar Lisesi öğrencilerinin Optimal Performans Duygu Durumlarıyla haftalık bireysel çalgıyla egzersiz yapma süresi arasında anlamlı farklılık var midır?

5. Güzel Sanatlar Lisesi öğrencilerinin Optimal Performans Duygu Durumları ve bireysel çalgılarıyla katıldıkları etkinliğin düzeyi arasında anlamlı farklılık var midir?

6. Güzel Sanatlar Lisesi öğrencilerinin Optimal Performans Duygu Durumlarıyla kişilik özellikleri arasında anlamlı bir ilişki var mıdır? 


\section{Yöntem}

\section{Araştırmanın Modeli}

$\mathrm{Bu}$ araştırmada, Güzel Sanatlar Lisesi öğrencilerinin optimal performans duygu durumlarına etki eden çeşitli değişkenleri incelemeyi amaçlanmış, bu sebeple betimsel nitelikte ilişkisel tarama modeli kullanılmıştır. Tarama araştırmaları genelde araştırmanın konusu ile ilgili durumu betimlemeyi amaçlamaktadır. "Bu tür araştırmalarda daha çok 'ne, nerede, ne zaman, ne sıklıkta, hangi düzeyde, nasıl' gibi soruların cevaplandırılmasına olanak tanır” (Büyüköztürk ve diğ, 2011). Karasar (2006)’ a göre “Tarama modeli bir olay, birey ya da nesneyi kendi koşulları içinde objektif olarak aktarmayı amaçlayan araştırma türü olarak açıklanmaktadır”. Bu modelde tasarlanan araştırmalarda, büyük bir topluluğun özelliklerini ya da görüşlerini belirlemek amacıyla topluluğu oluşturan bireylerden büyük bir parça seçilmektedir (Fraenkel ve Wallen, 2006). Bu açıklamaya göre araştırmada, Güzel Sanatlar Lisesi öğrencilerinin optimal performans duygu durumları arasında anlamlı bir farklılaşma olup olmadığını belirlemek amacıyla ilişkisel tarama modeli kullanılmıştır

\section{Çalışma evreni}

$\mathrm{Bu}$ araştırmanın evrenini Türkiye'deki Güzel Sanatlar Liseleri müzik bölümünde müzik eğitimi alan öğrencilerinin tümü, örneklemini ise, 2018-2019 Eğitim-Öğretim yılında, Orta Karadeniz Bölgesi'nde yer alan Amasya, Çorum, Ordu, Samsun ve Tokat illerindeki Güzel Sanatlar Liseleri (Amasya Güzel Sanatlar Lisesi, Çorum Güzel Sanatlar Lisesi, Ordu Penbe-İzzet Şahin Güzel Sanatlar Lisesi, Samsun İlkadım Güzel Sanatlar Lisesi ve Tokat Güzel Sanatlar Lisesi) müzik bölümünde müzik eğitimi alan her sınıf düzeyinde seçkisiz yöntemle belirlenmiş toplam (189 kadın, 111 erkek) 300 öğrenci oluşturmaktadır.

\section{Veri Toplama Araçları}

$\mathrm{Bu}$ araştırmada veri toplama (ölçme) aracı olarak, Çalışmaya katılan öğrencilerin kişilik özelliklerini ölçmek üzere beş temel kişilik özelliğinin ölçüldüğü "Rammstedt ve John (2007) tarafından geliştirilen, Horzum ve diğ. (2017) tarafından Türkçeye uyarlanarak geçerlik ve güvenirlik çalışması yapılan 10 maddeli "Beş Faktör Kişilik Ölçeği” ve öğrencilerin optimal performans duygu durumlarını ölçmek üzere ise Jackson ve Eklund (2002) tarafından geliştirilen ve Aşçı ve diğ. (2007) tarafından Türkçeye uyarlanarak, geçerlik ve güvenirlik çalışması yapılan 36 madde ve dokuz faktörden oluşan Durumluk ve Sürekli Optimal Performans Duygu Durum 2 Ölçeklerinden SOPDDÖ-2 kullanılmıştır. 
Araştırmada kullanılan Beş Faktör Kişilik Ölçeği ve Sürekli Optimal Performans Duygu Durum 2'nin bu çalışma için uygunluğu Alpha Modeli ile güvenirliklerine (içtutarlılık) bakılarak kontrol edilmiş ve araştırma analizlerine geçilmiştir. Araştırmada kullanılan ölçeklere yönelik ayrıntılı bilgiler aşağıda belirtilmektedir.

Araştırmaya katılan Güzel Sanatlar Lisesi öğrencilerinin kişilik özelliklerini ölçmek üzere beş temel kişilik özelliğinin ölçüldüğü "Rammstedt ve John (2007) tarafından geliştirilen, Horzum ve diğ. (2017) tarafından Türkçeye uyarlanan, 5'i olumsuz 5'i olumlu toplam 10 madde ve 5 boyuttan oluşan “Beş Faktör Kişilik Ölçeği”” kullanılmıştır. Ölçeğin maddeleri, çalışmaya katılan öğrenciler tarafından 'Hiçbir zaman' (1) ve 'Her zaman' (5) arasında değişen 5'li likert tipi seçeneklerinden biri seçilerek değerlendirilmektedir. Ölçeğin açıklayıcı faktör analizi çalışmalarında 218 lise öğrencisi yer almış ve beş boyuttan oluşan ölçeğin faktör yükleri Dışadönüklük \%19.4, Yumuşakbaşl1lık \%15, Özdenetimlilik \%18.4, Nörotiklik \%4.7, Deneyime açıklık \%30.9, olarak sıralanmıştır. Ölçeğin güvenirliğine Cronbach alfa iç tutarlılık ve kompozit güvenirlik katsayıları ile bakılmış kişilik yapılarındaki beş faktörü için iç tutarlılık ve kompozit güvenirlik değerleri dışadönüklük için iç tutarlılık. 88 ve kompozit .83; yumuşakbaşlılık için iç tutarlılık .81 ve kompozit .73; öz denetimlilik için iç tutarlılık .90 ve kompozit .85 , nörotiklik için iç tutarlılık .85 ve kompozit .79 ve deneyime açıklık için iç tutarlılık .84 ve kompozit .78 güvenirlik değerine sahip olduğu sonucuna ulaşılmıştır. Yapılan çalışmanın bulgularından hareketle Beş Faktör Kişilik Ölçeğinin Türk kültüründe geçerli ve güvenir bir ölçme aracı olduğu ve lise öğrencilerinde kişiliği ölçmek amacıyla kullanılabileceği vurgulanmıştır. (Horzum ve diğ., 2017).

Araştırmaya katılan Güzel Sanatlar Liselerinde müzik eğitimi alan öğrencilerin optimal performans duygu durumlarını ölçmek amacı ile Jackson ve Marsh (1996) tarafından oluşturulup Jackson ve diğ.. (1998) tarafından geliştirilen; Jackson ve Eklund (2002) tarafından yeniden düzenlenip Aşçı ve diğerleri (2007) tarafından Türkçeye uyarlanarak geçerlik ve güvenirlik çalışması yapılan toplam 36 madde ve 9 alt boyuttan oluşan Durumluk ve Sürekli Optimal Performans Duygu Durum 2 Ölçeklerinden "SOPDDÖ-2" kullanılmış ve araştırmada optimal performans duygu durum ölçeği başlığı altında kullanılmıştır Ölçek, 5'li Likert tipinde düzenlenmiş ve maddeleri çalışmaya katılan öğrenciler tarafından 'Hiçbir 
zaman' (1) ile 'Her zaman (5) seçeneklerinden biri seçilerek değerlendirilmektedir. Araştırmacılar tarafından ölçeğin Türkçeye uyarlanma çalışması sırasında dokuz boyutlu bir yapıda olduğu tespit edilerek alt boyutlara ilişkin hesaplanan güvenirlik (iç-tutarlılık) katsayıları sırasıyla Görev Zorluğu Beceri Dengesi 0.55, Eylem farkındalık birleşimi 0,60, Açık net hedefler 0,76, Belirli geri bildirim 0,80, Kontrol duygusu 0,78, Göreve odaklanma 0,77, Kendilik Farkındalığının Azalması 0,87, Zamanın dönüşümü 0,82, ve Amaca ulaşma deneyimi 0,63 şeklinde hesaplanmıştır.

\section{Verilerin Analizi}

$\mathrm{Bu}$ çalışmada verilerin analizinde araştırmaya katılan öğrencilerden, Kişisel Bilgi Formu, Kişilik Özellikleri ve Optimal Performans Duygu Durum Ölçekleri ile toplanan verilerin tamamı IBM SPSS Statistics 22.0 programına girilerek analiz edilmiştir.

Katılımcılardan elde edilen verilerin analizinden önce, verilerin anket ile belirlenen sınırlar içinde bulunup bulunmadığı, ciddi eksiklikler ve hatalar ihtiva edip etmediği kontrol edilmiştir. Çalışmanın amacı doğrultusunda uygulanacak istatistikî analizlerin belirlenebilmesi (parametrik veya nonparametrik) için Kolmogorov-Smirnov (K-S) testi $(\mathrm{p}<0.05)$, Skewness (Çarpıklık) - Kurtsosis (Basıklık) (+2 -2 aralı̆̆ı) değerleri incelenerek veri gruplarının normal dağıldıkları tablo 1.’ deki gibi belirlenmiştir.

Tablo 1. Öğrencilerin Optimal Performans Duygu Durum Ölçeği Puanları Üzerindeki Normallik Dağılımlarına İliş̧kin Kolmogorov - Smirnov ve Skewness (Çarpıklık) - Kurtsosis (Basıklık) Testleri

\begin{tabular}{lccc}
\hline & $\begin{array}{c}\text { Kolmogorov- } \\
\text { Smirnov (K- } \\
\text { Se testi }\end{array}$ & $\begin{array}{c}\text { Skewness } \\
\text { (Çarpisklı) }\end{array}$ & $\begin{array}{c}\text { Kurtosis } \\
\text { (Basıklı) }\end{array}$ \\
\hline Cinsiyet & 0,00 & 0,54 & $-1,71$ \\
Sinıfi & 0,00 & 0,22 & $-1,28$ \\
Bireysel çalgılar & 0,00 & 0,15 & $-0,70$ \\
Bireysel çalgıyı çalma süresi & 0,00 & $-0,00$ & $-0,26$ \\
Bireysel çalgısı ile haftalık egzersiz & 0,00 & 0,42 & $-1,07$ \\
sayısı & & & $-1,98$ \\
Bireysel çalgısı ile katıldığı etkinlik & 0,00 & 0,16 & 1,00 \\
düzeyi & & & \\
Kişilik özellikleri & 0,01 & $-0,18$ & \\
\hline$(\mathrm{p}<0.05)$ ve $(+2,-2)$ & & &
\end{tabular}

Araştırmada sırasıyla aşağıdaki şu testler kullanılmıştır: 
- Öğrencilerin kişisel (demografik) özelliklerini özetleyen betimsel istatistik analizi,

- Öğrencilerin Optimal performans duygu durum düzeyleri ve alt boyutları ile cinsiyetleri arasındaki farklılıklar için bağımsız/ilişkisiz gruplar t-testi

- Öğrencilerin Optimal performans duygu durum düzeyleri ve alt boyutları ile sınıf düzeyleri arasındaki farklılıklar için tek-yönlü varyans analizi (one-way ANOVA)

- Öğrencilerin Optimal performans duygu durum düzeyleri ve alt boyutları ile bireysel çalgıları arasındaki farklılıklar için tek-yönlü varyans analizi (one-way ANOVA) ve anlamlı fark tespit edilen durumlarda ise hangi gruplar arasında anlamlı fark olduğunu araştırmak için post-hoc Scheffe testi

- Öğrencilerin Optimal performans duygu durumu alt boyutları ile bireysel çalgılarını çalma süreleri(yıl) arasındaki farklılıklar için tek-yönlü varyans analizi (one-way ANOVA)

- Öğrencilerin Optimal performans duygu durum düzeyleri ve alt boyutları ile bireysel çalgılarıyla yapmış oldukları etkinlik katılım düzeyi arasındaki farklılıklar için bağımsız/ilişkisiz gruplar t-testi

Araştırmada yapılan tüm istatistiksel hesaplamalarda temel anlamlılık seviyesi 0,05 olarak kabul edilmiştir.

\section{Bulgular}

Tablo 2. Öğrencilerin Optimal Performans Duygu Durumu Düzeylerinin Cinsiyete Göre Karşılaştırılmasına Yönelik T-Testi (N=300)

\begin{tabular}{lccccccc}
\hline $\begin{array}{l}\text { Görev zorluğu beceri } \\
\text { dengesi }\end{array}$ & Kadın & 189 & 3,46 & 0,75 & 2,12 & 298 & $0,035^{*}$ \\
& Erkek & 111 & 3,64 & 0,68 & & & \\
\hline $\begin{array}{l}\text { Eylem farkındalık } \\
\text { birleşimi }\end{array}$ & Kadın & 189 & 2,98 & 0,68 & 1,24 & 298 & 0,214 \\
& Erkek & 111 & 3,09 & 0,70 & & & \\
\hline & Kadın & 189 & 3,66 & 0,86 & 0,45 & 298 & 0,651 \\
\hline Açık net hedefler & Erkek & 111 & 3,71 & 0,74 & & & \\
\hline Belirli geri bildirim & Kadın & 189 & 3,38 & 0,92 & 1,92 & 298 & 0,055
\end{tabular}


Erkek $\quad 111 \quad 3,58 \quad 0,75$

\begin{tabular}{lccccccc}
\hline & Kadın & 189 & 3,41 & 0,80 & 0,11 & 298 & 0,906 \\
Göreve odaklanma & Erkek & 111 & 3,42 & 0,74 & & & \\
& Kadın & 189 & 3,59 & 0,76 & 0,45 & 298 & 0,649 \\
Kontrol duygusu & Erkek & 111 & 3,55 & 0,69 & & & \\
\hline Kendilik fark. & Kadın & 189 & 3,05 & 1,01 & 0,31 & 298 & 0,755 \\
azalması & Erkek & 111 & 3,08 & 0,99 & & & \\
\hline & Kadın & 189 & 3,51 & 0,77 & 0,82 & 298 & 0,411 \\
Zamanın dönüşümü & Erkek & 111 & 3,43 & 0,81 & & & \\
\hline Amaca ulaşma & Kadın & 189 & 4,10 & 0,82 & 1,87 & 298 & 0,062 \\
deneyimi & Erkek & 111 & 3,92 & 0,81 & & & \\
\hline & Kadın & 189 & 3,46 & 0,55 & 0,48 & 298 & 0,628 \\
OPDD ortalama & Erkek & 111 & 3,49 & 0,50 & & & \\
\hline
\end{tabular}

Tablo incelendiğinde öğrencilerin Optimal Performans Duygu Durumlarıyla cinsiyetleri arasında anlamlı farklılığın olup olmadığını belirlemek için bağımsız/ilişkisiz gruplar t- testi uygulanmıştır. Test sonuçlarına göre yalnızca Optimal performans duygu durumunun alt boyutlarından Görev zorluğu beceri dengesi düzeyleri ile kadın ve erkek öğrencilerin cinsiyetleri arasında anlamlı bir farklılığın olduğu ve anlamlı farklılığın erkek öğrenciler lehine olduğu tespit edilmiştir $[\mathrm{t}(300)=3,64 ; \mathrm{p}<.05]$. Gruplara ait ortalama puanlar incelendiğinde, erkek öğrencilerin $\left(\bar{X}_{\text {Erkek }}=3,64\right)$ görev zorluğu - beceri dengesi düzeyinin, kadın öğrencilerin Görev zorluğu beceri dengesi düzeyinden $\left(\bar{X}_{\text {Kadın }}=3,46\right)$ daha yüksek olduğu görülmektedir.

Tablo 3. Öğrencilerin Optimal Performans Duygu Durumu Düzeylerinin Bireysel Çalgı Türlerine Göre Karşılaştırılmasına Yönelik ANOVA Testi (N=300)

\begin{tabular}{llcccccc}
\hline & Bireysel & \multicolumn{3}{c}{ Betimsel istatistik } & \multicolumn{2}{c}{ ANOVA } & Scheffe Test \\
\cline { 2 - 7 } Puan & Çalg1 & $\mathrm{n}$ & $\overline{\mathrm{x}}$ & ss & $\mathrm{F}$ & $\mathrm{p}$ & \\
\hline Görev zorluğu & Telli(1) & 89 & 3,50 & 0,76 & 0,62 & 0,536 & -
\end{tabular}




\begin{tabular}{|c|c|c|c|c|c|c|c|}
\hline \multirow[t]{2}{*}{ beceri dengesi } & Yaylı(2) & 165 & 3,51 & \multicolumn{2}{|l|}{0,72} & & \\
\hline & Üflemeli(3) & 46 & 3,64 & 0,68 & & & \\
\hline$\overline{\text { Eylem }}$ & Telli(1) & 89 & 2,98 & 0,69 & 0,66 & 0,514 & - \\
\hline farkındalık & Yaylı(2) & 165 & 3,01 & 0,64 & & & \\
\hline birleşimi & Üflemeli(3) & 46 & 3,13 & 0,83 & & & \\
\hline Açık net & Telli(1) & 89 & 3,66 & 0,84 & 2,13 & 0,121 & - \\
\hline hedefler & Yaylı(2) & 165 & 3,63 & 0,83 & & & \\
\hline & Üflemeli(3) & 46 & 3,91 & 0,71 & & & \\
\hline Belirli geri & Telli(1) & 89 & 3,52 & 0,84 & 2,60 & 0,076 & - \\
\hline bildirim & Yaylı(2) & 165 & 3,36 & 0,86 & & & \\
\hline & Üflemeli(3) & 46 & 3,67 & 0,88 & & & \\
\hline Göreve & Telli(1) & 89 & 3,43 & 0,79 & 0,09 & 0,906 & - \\
\hline odaklanma & Yaylı(2) & 165 & 3,41 & 0,79 & & & \\
\hline & Üflemeli(3) & 46 & 3,36 & 0,75 & & & \\
\hline Kontrol & Telli(1) & 89 & 3,54 & 0,75 & 0,80 & 0,451 & - \\
\hline duygusu & Yaylı(2) & 165 & 3,56 & 0,76 & & & \\
\hline & Üflemeli(3) & 46 & 3,70 & 0,62 & & & \\
\hline Kendilik fark. & Telli(1) & 89 & 3,03 & 1,00 & 0,05 & 0,944 & - \\
\hline azalması & Yaylı(2) & 165 & 3,07 & 0,99 & & & \\
\hline & Üflemeli(3) & 46 & 3,07 & 1,06 & & & \\
\hline Zamanın & Telli(1) & 89 & 3,42 & 0,76 & 0,44 & 0,644 & - \\
\hline dönüşümü & Yaylı(2) & 165 & 3,50 & 0,76 & & & \\
\hline & Üflemeli(3) & 46 & 3,53 & 0,91 & & & \\
\hline Amaca ulaşma & Telli(1) & 89 & 3,85 & 0,88 & 3,34 & $0,037 *$ & 2 ile 1,3 \\
\hline deneyimi & Yaylı(2) & 165 & 4,12 & 0,78 & & & \\
\hline & Üflemeli(3) & 46 & 4,07 & 0,77 & & & \\
\hline OPDD ortalam & aTelli(1) & 89 & 3,44 & 0,54 & 0,89 & 0,409 & - \\
\hline & Yaylı(2) & 165 & 3,46 & 0,54 & & & \\
\hline & Üflemeli(3) & 46 & 3,56 & 0,49 & & & \\
\hline
\end{tabular}

Tablo 3'de Güzel Sanatlar Lisesi öğrencilerinin optimal performans duygu durumları ile bireysel çalgı türleri arasında anlamlı bir farklılık olup olmadığına ilişkin tek-yönlü varyans 
analizi (one-way ANOVA) uygulanmıştır. Test sonuçlarına göre yalnızca optimal performans duygu durumunun alt boyutlarından amaca ulaşma deneyimi düzeyleri ile öğrencilerin bireysel çalgı türleri arasında anlamlı bir farklılı̆̆ın olduğu tespit edilmiştir $\left[F_{(2 ; 300)}=3,34\right.$; $\mathrm{p}<.05]$. Ayrıca yapılan Post-hoc Scheffe testi sonuçlarına göre; yaylı çalgı çalan öğrencilerin $\left(\overline{\mathrm{X}}_{\text {Yaylı }}=4,25\right)$ amaca ulaşma deneyimi düzeyleri telli ve üflemeli çalgı çalan öğrencilerden yüksektir ( $\left.\overline{\mathrm{X}}_{\text {Telli }}=3,85 ; \overline{\mathrm{X}}_{\text {Üflemeli }}=4,07\right)$.

Tablo 4. Öğrencilerin Optimal Performans Duygu Durumu Düzeylerinin Bireysel Çalgılarını Çalma Sürelerine Göre Karşılaştırılmasına Yönelik One Way ANOVA Testi (N=300)

\begin{tabular}{|c|c|c|c|c|c|c|c|}
\hline \multirow[b]{2}{*}{ Puan } & \multirow{2}{*}{$\begin{array}{l}\text { Bireysel Çalg1 } \\
\text { Çalma Süresi }\end{array}$} & \multicolumn{2}{|c|}{ Betimsel istatistik } & \multirow[b]{2}{*}{ SS } & \multicolumn{2}{|c|}{ ANOVA } & \multirow[t]{2}{*}{ Scheffe Test } \\
\hline & & $\mathrm{n}$ & $\overline{\mathrm{x}}$ & & $\mathrm{F}$ & $\mathrm{P}$ & \\
\hline Görev zorluğu & 1 y1ldan az(1) & 23 & 3,77 & 0,79 & 3,00 & $0,05^{*}$ & 1 ile 2,3 \\
\hline \multirow[t]{2}{*}{ beceri dengesi } & $1-3$ y1l $\operatorname{arasi}(2)$ & 191 & 3,45 & 0,71 & & & \\
\hline & 4 y1l ve üzr.(3) & 86 & 3,62 & 0,74 & & & \\
\hline Eylem & 1 y1ldan az(1) & 23 & 2,85 & 0,61 & 3,35 & $0,03^{*}$ & 1, 2 ile 3 \\
\hline farkındalık & $1-3$ y1l $\operatorname{arasi}(2)$ & 191 & 2,97 & 0,67 & & & \\
\hline birleşimi & 4 y1l ve üzr.(3) & 86 & 3,18 & 0,74 & & & \\
\hline Aç1k net & 1 yildan az(1) & 23 & 3,90 & 0,91 & 1,83 & 0,16 & \\
\hline \multirow[t]{2}{*}{ hedefler } & $1-3$ y1l $\operatorname{arasi}(2)$ & 191 & 3,62 & 0,79 & & & \\
\hline & 4 y1l ve üzr.(3) & 86 & 3,77 & 0,84 & & & \\
\hline Belirli geri & 1 y1ldan az(1) & 23 & 3,81 & 0,99 & 5,16 & $0,00^{*}$ & 1 ile 2,3 \\
\hline \multirow[t]{2}{*}{ bildirim } & $1-3$ y1l $\operatorname{arasi}(2)$ & 191 & 3,34 & 0,85 & & & \\
\hline & 4 y1l ve üzr.(3) & 86 & 3,61 & 0,81 & & & \\
\hline Göreve & 1 yıldan az(1) & 23 & 3,56 & 0,85 & 2,96 & 0,06 & \\
\hline \multirow[t]{2}{*}{ odaklanma } & 1-3 y1l aras1(2) & 191 & 3,33 & 0,77 & & & \\
\hline & 4 y1l ve üzr.(3) & 86 & 3,55 & 0,78 & & & \\
\hline Kontrol & 1 y1ldan az(1) & 23 & 3,78 & 0,81 & 0,96 & 0,38 & \\
\hline \multirow[t]{2}{*}{ duygusu } & $1-3$ y1l $\operatorname{arasi}(2)$ & 191 & 3,55 & 0,70 & & & \\
\hline & 4 y1l ve üzr.(3) & 86 & 3,58 & 0,79 & & & \\
\hline \multirow{3}{*}{$\begin{array}{l}\text { Kendilik fark. } \\
\text { azalması }\end{array}$} & 1 yildan az(1) & 23 & 2,85 & 0,94 & 0,75 & 0,47 & \\
\hline & $1-3$ y1l $\operatorname{arasi}(2)$ & 191 & 3,05 & 1,03 & & & \\
\hline & 4 y1l ve üzr.(3) & 86 & 3,14 & 0,95 & & & \\
\hline
\end{tabular}




\begin{tabular}{|c|c|c|c|c|c|c|c|}
\hline \multirow{3}{*}{$\begin{array}{l}\text { Zamanın } \\
\text { dönüşümü }\end{array}$} & 1 y1ldan az(1) & 23 & 3,79 & 0,72 & \multirow[t]{3}{*}{1,92} & \multirow[t]{3}{*}{0,14} & \\
\hline & $1-3$ y1l arası(2) & 191 & 3,45 & 0,80 & & & \\
\hline & 4 y1l ve üzr.(3) & 86 & 3,47 & 0,74 & & & \\
\hline \multirow{3}{*}{$\begin{array}{l}\text { Amaca ulaşma } \\
\text { deneyimi }\end{array}$} & 1 yldan az(1) & 23 & 4,17 & 0,67 & \multirow[t]{3}{*}{0,41} & \multirow[t]{3}{*}{0,66} & \\
\hline & $1-3$ y1l $\operatorname{arasi}(2)$ & 191 & 4,01 & 0,81 & & & \\
\hline & 4 y1l ve üzr.(3) & 86 & 4,05 & 0,88 & & & \\
\hline \multirow{3}{*}{$\begin{array}{l}\text { OPDD } \\
\text { ortalama }\end{array}$} & 1 y1ldan az(1) & 23 & 3,61 & 0,58 & \multirow[t]{3}{*}{2,68} & \multirow[t]{3}{*}{$0,07 *$} & 1 ile 2,3 \\
\hline & $1-3$ y1l $\operatorname{arasi}(2)$ & 191 & 3,42 & 0,50 & & & \\
\hline & 4 y1l ve üzr.(3) & 86 & 3,55 & 0,57 & & & \\
\hline
\end{tabular}

Tabloda Güzel Sanatlar Lisesi öğrencilerinin optimal performans duygu durumları ile bireysel çalgılarını çalma süreleri arasında anlamlı bir farklılık olup olmadığına ilişkin tek-yönlü varyans analizi (one-way ANOVA) uygulanmıştır. Test sonuçlarına göre yalnızca öğrencilerin bireysel çalgılarını çalma süreleri optimal performans duygu durumu ve alt boyutlarından görev zorluğu beceri dengesi, eylem farkındalık birleşimi, belirli geri bildirim düzeyleri arasında anlamlı bir farklılık olduğu tespit edilmiştir. Araştırmaya katılan öğrencilerden bireysel çalgısını 1 yıldan az süredir çalanların görev zorluğu beceri dengesi düzeyleri diğer gruplardan daha yüksektir $[\mathrm{F}(1 ; 300)=3,77 ; \mathrm{p}<.05]$. Araştırmaya katılan öğrencilerden bireysel çalgısını 4 yıl ve üzeri süredir çalanların eylem farkındalık birleşimi düzeyleri diğer gruplardan daha yüksektir $[\mathrm{F}(3 ; 300)=3,18 ; \mathrm{p}<.05]$. Araştırmaya katılan öğrencilerden bireysel çalgısını 1 yıldan az süredir çalanların belirli geri bildirim düzeyleri diğer gruplardan daha yüksektir $[\mathrm{F}(1 ; 300)=3,81 ; \mathrm{p}<.05]$. Araştırmaya katılan öğrencilerden bireysel çalgısını 1 yıldan az süredir çalanların Optimal performans duygu durum düzeyleri diğer gruplardan daha yüksektir $[\mathrm{F}(1 ; 300)=3,61 ; \mathrm{p}<.05]$.

Tablo 5. Öğrencilerin Optimal Performans Duygu Durumu Düzeylerinin Bireysel Çalgılarıyla Yaptıkları Haftalık Egzersiz Sayısına Göre Karşılaştırılmasına Yönelik ANOVA Testi $(\mathrm{N}=300)$

\begin{tabular}{|c|c|c|c|c|c|c|c|}
\hline \multirow[b]{2}{*}{ Puan } & \multirow{2}{*}{$\begin{array}{l}\text { Bry. Çl. Hf. } \\
\text { Egz sayısı }\end{array}$} & \multicolumn{3}{|c|}{ Betimsel istatistik } & \multicolumn{2}{|c|}{ ANOVA } & \multirow{2}{*}{$\begin{array}{c}\text { Scheffe } \\
\text { Test }\end{array}$} \\
\hline & & $\mathrm{n}$ & $\overline{\mathrm{x}}$ & SS & $\mathrm{F}$ & $\mathrm{p}$ & \\
\hline Görev & $1-3 \mathrm{kez}(1)$ & 127 & 3,31 & 0,72 & 14,7 & $0,00^{*}$ & 1 ile 2,3 \\
\hline zorluğu & 4-6 kez(2) & 119 & 3,57 & 0,68 & & & \\
\hline
\end{tabular}




\begin{tabular}{|c|c|c|c|c|c|c|c|}
\hline $\begin{array}{l}\text { beceri } \\
\text { dengesi }\end{array}$ & 7 ve üzeri(3) & 54 & 3,92 & 0,67 & & & \\
\hline Eylem & $1-3 \mathrm{kez}(1)$ & 127 & 2,95 & 0,72 & 1,36 & 0,25 & \\
\hline farkındalık & 4-6 kez(2) & 119 & 3,05 & 0,60 & & & \\
\hline birleşimi & 7 ve üzeri(3) & 54 & 3,12 & 0,79 & & & \\
\hline Aç1k net & $1-3 \mathrm{kez}(1)$ & 127 & 3,51 & 0,84 & 10,1 & $0,00 *$ & 1 ile 2,3 \\
\hline \multirow[t]{2}{*}{ hedefler } & 4-6 kez(2) & 119 & 3,67 & 0,77 & & & \\
\hline & 7 ve üzeri(3) & 54 & 4,10 & 0,73 & & & \\
\hline Belirli geri & 1-3 kez1(1) & 127 & 3,36 & 0,91 & 7,86 & $0,00 *$ & 1 ile 2,3 \\
\hline \multirow[t]{2}{*}{ bildirim } & 4-6 kez(2) & 119 & 3,37 & 0,80 & & & \\
\hline & 7 ve üzeri(3) & 54 & 3,87 & 0,79 & & & \\
\hline Göreve & $1-3 \mathrm{kez}(1)$ & 127 & 3,20 & 0,81 & 9,07 & $0,00 *$ & 1 ile 2,3 \\
\hline \multirow[t]{2}{*}{ odaklanma } & 4-6 kez(2) & 119 & 3,51 & 0,75 & & & \\
\hline & 7 ve üzeri(3) & 54 & 3,68 & 0,64 & & & \\
\hline$\overline{\text { Kontrol }}$ & $1-3 \mathrm{kez}(1)$ & 127 & 3,43 & 0,78 & 5,26 & $0,00 *$ & 1 ile 2,3 \\
\hline \multirow[t]{2}{*}{ duygusu } & 4-6 kez(2) & 119 & 3,64 & 0,68 & & & \\
\hline & 7 ve üzeri(3) & 54 & 3,78 & 0,68 & & & \\
\hline Kendilik & $1-3 \mathrm{kez}(1)$ & 127 & 3,04 & 1,04 & 0,88 & 0,41 & \\
\hline fark. & 4-6 kez(2) & 119 & 3,01 & 0,92 & & & \\
\hline azalması & 7 ve üzeri(3) & 54 & 3,22 & 1,06 & & & \\
\hline Zamanın & $1-3 \operatorname{kez}(1)$ & 127 & 3,43 & 0,77 & 1,58 & 0,20 & \\
\hline \multirow[t]{2}{*}{ dönüşümü } & 4-6 kez(2) & 119 & 3,58 & 0,74 & & & \\
\hline & 7 ve üzeri(3) & 54 & 3,39 & 0,89 & & & \\
\hline \multirow{3}{*}{$\begin{array}{l}\text { Amaca } \\
\text { ulaşma } \\
\text { deneyimi }\end{array}$} & $1-3 \mathrm{kez}(1)$ & 127 & 3,82 & 0,86 & 7,75 & $0,00^{*}$ & 1 ile 2,3 \\
\hline & 4-6 kez(2) & 119 & 4,15 & 0,75 & & & \\
\hline & 7 ve üzeri(3) & 54 & 4,26 & 0,75 & & & \\
\hline \multirow{3}{*}{$\begin{array}{l}\text { OPDD } \\
\text { ortalama }\end{array}$} & $1-3 \mathrm{kez}(1)$ & 127 & 3,34 & 0,58 & 9,85 & $0,00 *$ & 1 ile 2,3 \\
\hline & 4-6 kez(2) & 119 & 3,51 & 0,46 & & & \\
\hline & 7 ve üzeri(3) & 54 & 3,70 & 0,47 & & & \\
\hline
\end{tabular}

Tablo 5’ e göre Güzel Sanatlar Lisesi öğrencilerinin optimal performans duygu durumları ile haftalık bireysel çalgıyla egzersiz yapma süreleri arasında anlamlı bir farklılık 
olup olmadığına ilişkin tek-yönlü varyans analizi (one-way ANOVA) uygulanmıştır. Test sonuçlarına göre öğrencilerin haftalık bireysel çalgıyla egzersiz yapma süreleri ile eylem farkındalık birleşimi, kendilik farkındalığının azalması ve zamanın dönüşümü alt boyutları hariç tüm boyutlar ve ortalamada anlamlı bir farklılık tespit edilmiştir. Araştırmaya katılan öğrencilerden bireysel çalgısı ile haftada 7 ve üzeri kez egzersiz yapanların sayısı görev zorluğu beceri dengesi düzeyleri diğer gruplardan daha yüksektir [F $(3 ; 300)=3,92 ; \mathrm{p}<.05]$. Araştırmaya katılan öğrencilerden bireysel çalgısı ile haftada 7 ve üzeri kez egzersiz yapanların sayısı açık net hedefler düzeyleri diğer gruplardan daha yüksektir $[\mathrm{F}(3 ; 300)=$ $4,10 ; \mathrm{p}<.05]$. Araştırmaya katılan öğrencilerden bireysel çalgısı ile haftada 7 ve üzeri kez egzersiz yapanların sayısı belirli geri bildirim düzeyleri diğer gruplardan daha yüksektir [F (3; $300)=3,87 ; \mathrm{p}<.05]$. Araştırmaya katılan öğrencilerden bireysel çalgısı ile haftada 7 ve üzeri kez egzersiz yapanların sayısı göreve odaklanma düzeyleri diğer gruplardan daha yüksektir [F $(3 ; 300)=3,68 ; p<.05]$. Araştırmaya katılan öğrencilerden bireysel çalgısı ile haftada 7 ve üzeri kez egzersiz yapanların sayısı kontrol duygusu düzeyleri diğer gruplardan daha yüksektir $[\mathrm{F}(3 ; 300)=3,78 ; \mathrm{p}<.05]$. Araştırmaya katılan öğrencilerden bireysel çalgııs ile haftada 7 ve üzeri kez egzersiz yapanların sayısı amaca ulaşma deneyimi düzeyleri diğer gruplardan daha yüksektir $[\mathrm{F}(3 ; 300)=4,26 ; \mathrm{p}<.05]$. Araştırmaya katılan öğrencilerden bireysel çalgısı ile haftada 7 ve üzeri kez egzersiz yapanların sayısı optimal performans duygu durumları düzeyleri diğer gruplardan daha yüksektir $[\mathrm{F}(3 ; 300)=3,70 ; \mathrm{p}<.05]$.

Güzel Sanatlar Lisesi öğrencilerinin optimal performans duygu durumları ve alt boyutları ile haftalık bireysel çalgıyla egzersiz yapma süreleri arasındaki anlamlı farklılık incelendiğinde hem genel ortalamada hem de alt boyutlarda bireysel çalgısı ile haftada 7 ve üzeri kez egzersiz yapanların en yüksek düzeylere ulaştığı tespit edilmiştir.

Tablo 6. Öğrencilerin Optimal Performans Duygu Durumu Düzeylerinin Etkinlik Katılım Düzeyine Göre Karşılaştırılmasına Yönelik T-Testi (N=300)

\begin{tabular}{lccccccc}
\hline $\begin{array}{l}\text { Görev zorluğu beceri } \\
\text { dengesi }\end{array}$ & Kons & 162 & 3,64 & 0,69 & 3,10 & 298 & $0,00^{*}$ \\
& Eğlen & 138 & 3,38 & 0,75 & & & \\
\hline $\begin{array}{l}\text { Eylem farkındalık } \\
\text { birleşimi }\end{array}$ & Kons & 162 & 3,13 & 0,71 & 3,03 & 298 & $0,00^{*}$ \\
& Eğlen & 138 & 2,89 & 0,64 & & & \\
\hline
\end{tabular}




\begin{tabular}{|c|c|c|c|c|c|c|c|}
\hline \multirow{2}{*}{ Açık net hedefler } & Kons & 162 & 3,83 & 0,80 & \multirow[t]{2}{*}{3,42} & \multirow[t]{2}{*}{298} & \multirow[t]{2}{*}{$0,00 *$} \\
\hline & Eğlen & 138 & 3,51 & 0,81 & & & \\
\hline \multirow{2}{*}{ Belirli geri bildirim } & Kons & 162 & 3,54 & 0,84 & 1,87 & 298 & 0,06 \\
\hline & Eğlen & 138 & 3,35 & 0,88 & & & \\
\hline \multirow{2}{*}{ Göreve odaklanma } & Kons & 162 & 3,52 & 0,80 & 2,77 & 298 & $0,00 *$ \\
\hline & Eğlen & 138 & 3,27 & 0,74 & & & \\
\hline \multirow{2}{*}{ Kontrol duygusu } & Kons & 162 & 3,67 & 0,74 & 2,41 & 298 & $0,01 *$ \\
\hline & Eğlen & 138 & 3,47 & 0,71 & & & \\
\hline \multirow{2}{*}{$\begin{array}{l}\text { Kendilik fark. } \\
\text { azalması }\end{array}$} & Kons & 162 & 3,08 & 0,97 & 0,32 & 298 & 0,74 \\
\hline & Eğlen & 138 & 3,04 & 1,04 & & & \\
\hline \multirow{2}{*}{ Zamanın dönüşümü } & Kons & 162 & 3,52 & 0,81 & 0,96 & 298 & 0,33 \\
\hline & Eğlen & 138 & 3,43 & 0,76 & & & \\
\hline \multirow{2}{*}{$\begin{array}{l}\text { Amaca ulaşma } \\
\text { deneyimi }\end{array}$} & Kons & 162 & 4,14 & 0,81 & 2,38 & 298 & $0,01 *$ \\
\hline & Eğlen & 138 & 3,91 & 0,81 & & & \\
\hline \multirow{2}{*}{ OPDD ortalama } & Kons & 162 & 3,56 & 0,52 & 3,30 & 298 & $0,00 *$ \\
\hline & Eğlen & 138 & 3,36 & 0,52 & & & \\
\hline
\end{tabular}

Tablo 6 incelendiğinde Güzel Sanatlar Lisesi öğrencilerinin Optimal Performans Duygu Durumları ve bireysel çalgılarıyla katıldıkları etkinliğin düzeyi arasında anlamlı farklılığın olup olmadığına ilişkin bağımsız/ilişkisiz gruplar t- testi uygulanmıştır. Test sonuçlarına göre öğrencilerin bireysel çalgılarıyla katıldıkları etkinliğin düzeyi ile belirli geri bildirim, kendilik farkındalığının azalması ve zamanın dönüşümü alt boyutları hariç tüm boyutlar ve ortalamada anlamlı bir farklılık tespit edilmiştir. Araştırmaya katılan öğrencilerden bireysel çalgısı ile konser, dinleti, yarışma, vs. düzeyinde etkinliğe katılanların görev zorluğu beceri dengesi düzeyleri ortalaması $[\mathrm{t}(300)=3,64 ; \mathrm{p}<.05]$; Eylem farkındalık birleşimi düzeyleri ortalaması $[\mathrm{t}(300)=3,13 ; \mathrm{p}<.05]$; Açık net hedefler düzeyleri ortalaması 
$[\mathrm{t}(300)=3,83 ; \mathrm{p}<.05] ;$ Göreve odaklanma düzeyleri ortalaması $[\mathrm{t}(300)=3,52 ; \mathrm{p}<.05]$; Kontrol duygusu düzeyleri ortalaması $[\mathrm{t}(300)=3,67 ; \mathrm{p}<.05]$; Amaca ulaşma deneyimi düzeyleri ortalaması $[\mathrm{t}(300)=4,14 ; \mathrm{p}<.05]$; Optimal Performans Duygu Durumu düzeyleri ortalaması $[\mathrm{t}(300)=3,56 ; \mathrm{p}<.05]$ olarak tespit edilmiştir.

Araştırmada konser, dinleti, yarışma vb. gibi etkinlik düzeyi katılımı gerçekleştiren öğrencilerin optimal performans duygu durumu düzeylerinin oldukça yüksek olduğu belirlenmiştir.

Tablo 7. Öğrencilerin Optimal Performans Duygu Durumu Düzeylerinin Kişilik Özelliklerine Göre Karşılaştırılmasına Yönelik Lineer Regresyon Testi (N=300)

\begin{tabular}{lccccc} 
Kişilik Özellikleri & $\mathrm{B}$ & $\mathrm{SEb}$ & $\mathrm{Beta}$ & $\mathrm{t}$ & $\mathrm{p}$ \\
\hline Dışadönüklük & 0,016 & 0,043 & 0,021 & 0,36 & 0,714 \\
Yumuşakbaşl1lık & 0,110 & 0,040 & 0,162 & 2,72 & $0,007^{*}$ \\
Özdenetimlilik & 0,116 & 0,041 & 0,164 & 2,83 & $0,005^{*}$ \\
Nörotiklik & 0,072 & 0,037 & 0,114 & 1,95 & 0,052 \\
Deneyime_açıklık & $-0,006$ & 0,040 & $-0,008$ & $-0,13$ & 0,890 \\
\hline
\end{tabular}

Tablo 7 incelendiğinde Güzel Sanatlar Lisesi öğrencilerinin Optimal Performans Duygu Durumları düzeyi ve kişilik özellikleri arasında anlamlı bir ilişkinin olup olmadığına ilişkin basit doğrusal (lineer) regresyon analizi yapılmıştır. Test sonuçlarına göre öğrencilerin yumuşakbaşlilık $(\mathrm{P}=0,07<0,05)$ ve özdenetimlilik $(\mathrm{p}=0,05<0,05)$ özellikleri ile optimal performans duygu durumu düzeyleri arasında lineer bir ilişki tespit edilirken, diğer kişilik özellikleri ile Optimal performans duygu durumları düzeyi arasında anlamlı bir ilişkiye rastlanmamıştır $(\mathrm{p}>0,05)$.

Güzel Sanatlar Lisesi öğrencilerinin yumuşakbaşl1lık ve özdenetimlilik kişilik özellikleri yükseldikçe optimum performans duygu durum düzeyleri de yükselmektedir. 


\section{Sonuç, Tartışma ve Öneriler}

Güzel Sanatlar Lisesi öğrencilerinin optimal performans duygu durumlarına etki eden değişkenler incelendiğinde öğrencilerin optimal performans duygu durum düzeyleri ortalaması ile bireysel çalgılarını kaç yıldır çaldıkları, bireysel çalgılarıyla yapmış oldukları haftalık egzersiz sayıları, bireysel çalgılarıyla katıldıkları etkinlik düzeyleri ve kişilik özellikleri yumuşakbaşlılık ve özdenetimlilik alt boyutları arasında anlamlı farklılıklar ve ilişkilere rastlanmıştır. Bununla birlikte optimal performans duygu durumunun alt boyutları ile öğrencilerin cinsiyetleri, bireysel çalgı türleri, bireysel çalgılarını kaç yıldır çaldıkları, bireysel çalgılarıyla yapmış oldukları haftalık egzersiz sayıları ve bireysel çalgılarıyla katıldıkları etkinlik düzeyleri arasında da anlamlı farklılıklar ve ilişkiler saptanmıştır. Öğrencilerin sınıf seviyeleri ile ilgili herhangi bir anlamlı farklılık tespit edilmemiştir.

Araştırmaya katılan öğrenciler cinsiyetleri bakımından ele alındığında erkek öğrencilerin optimal performans duygu durum düzeylerinin kadın öğrencilerin düzeylerinden yüksek olduğu fakat alt boyutlar ele alındığında anlamlı bir farklılık olmadığı görülmüştür. Dolayısıyla bu sonuca göre optimal performans duygu durumu ortalama puanı yüksek olan erkek öğrencilerin bireysel çalgılarına yönelik çalışmalarından kadın öğrencilere göre daha yüksek haz ve doyum elde ettikleri söylenebilmektedir. Çetinkalp (2011)'in optimal performans duygu durum başlığı altında yapmış olduğu çalışmasında kadın katılımcıların görev zorluğu beceri dengesi ve belirli geri bildirim alt boyutu düzeylerinin erkek katılımcıların düzeylerinden anlamlı biçimde düşük, buna karşın amaca ulaşma deneyimi alt boyutu düzeylerinde erkek katılımcıların düzeyinin anlamlı biçimde yüksek olduğunu tespit ederek, bu bulgunun erkeklerin yapacağı harekete ilişkin detaylara daha az yoğunlaşmalarıyla ve akış durumu için kendine daha rahat bir ortam yaratmalarıyla açıklamıştır. Kadın dansçıların ise yalnızca aktivitenin kendisi için fiziksel aktiviteye katıldıklarını bununla birlikte yaptıkları aktiviteden aldıkları içsel doyumun, hazzın erkeklerden daha fazla olduğunu vurgulamıştır.

Öğrencilerin bireysel çalgı türleri ele alındığında optimal performans duygu durumu düzeyi genel ortalamasında herhangi bir farklılık görülmemişken, alt boyutlardan amaca ulaşma deneyimine yönelik yaylı çalgılar grubundaki öğrencilerin düzeyinin diğer iki gruptaki öğrencilerin düzeylerinden daha yüksek olduğuna ulaşılmıştır. Bu durumla ilgili olarak Güzel 
Sanatlar Liselerinde özellikle orkestralarda çoğunluk grubun yaylı çalgılar çalan öğrencilerden oluşmasının etkisinden söz edilebilir.

Araştırmaya katılan öğrencilerin bireysel çalgılarını kaç yıldır çaldıkları ile ilgili bulgular incelendiğinde, 1 yıldan az süredir bireysel çalgısını çalan öğrencilerin optimal performans duygu durumu düzeyi genel ortalaması, görev zorluğu beceri dengesi ve belirli geri bildirim düzeyleri diğer iki gruptan yüksek çıktığı görülmüştür ve ayrıca bireysel çalgısını 4 yıl ve üzeri süredir çalan öğrencilerin eylem farkındalık birleşimi düzeylerinin diğer iki gruptan yüksek olduğu belirlenmiştir.

Öğrencilerin bireysel çalgılarıyla yapmış olduğu haftalık egzersiz sayıları bakımından ele alındığında 7 ve üzeri kez haftalık egzersiz yapanların optimal performans duygu durumu düzeyleri ve alt boyutlarından görev zorluğu beceri dengesi, açık net hedefler, belirli geri bildirim, göreve odaklanma, kontrol duygusu ve amaca ulaşma deneyimi düzeylerinin diğer iki gruptan daha yüksek olduğu bulunmuştur. Bu bulgular doğrultusunda bireysel çalgısıyla daha çok egzersiz yapan öğrencilerin bireysel çalgılarıyla geçirdikleri zaman diliminden akış(flow) deneyimleme, içsel doyum ve haz elde etmeleri daha yüksek olacaktır. Öğrenciler çalgıları ile ne kadar çok vakit geçirir düzenli disiplinli olarak çalışırsa o kadar çok becerilerini geliştirme ve bu zaman diliminden haz alma mutlu olma firsatı da elde edecekler denilebilir. Öğrenciler ders dışındaki çalışmalarında yani egzersiz zamanlarında geliştirdiği bireysel becerilerini de kullanma firsatını elde eder. Ayrıca bu konu ile ilintili olarak boş zamanların değerlendirilmesi bağlamında Akış kuramını ortaya koyan Csikszentmihalyi "becerilerin kullanımıyla ortaya çıkan akış gelişmeye neden olur" şeklinde belirtmektedir (Csikszentmihalyi, 2017).

Araştırmanın diğer bir bulgusuna göre öğrencilerin bireysel çalgılarıyla yapmış oldukları etkinliğe katılım düzeyleri bakımından konser, dinleti, yarışma, vb. gibi etkinliklere katılanların optimal performans duygu durumları düzeyi ve alt boyutlardan görev zorluğu beceri dengesi, eylem farkındalık birleşimi, açık net hedefler, göreve odaklanma, kontrol duygusu ve amaca ulaşma deneyimi düzeylerinin bu tür etkinliklere katılmayan öğrencilere göre daha yüksek olduğu tespit edilmiştir. Güzel sanatlar liselerinde öğrenim gören müzik bölümü öğrencilerinin bireysel çalgılarını sergiledikleri ciddi etkinlikler olarak görülen konser, dinleti ve yarışma gibi etkinlikler çalgılarında gelişimlerinin değerlendirilmesinde çok önemli bir yere sahiptir. Bu anlamda deneyimli öğrencilerin akış (flow) deneyimlemesi 
çalgılarıyla katıldıkları bu etkinliklerden yoğun haz ve içsel doyum elde etmeleri çalgı başarılarını arttırmada oldukça önemli olduğu düşünülmektedir.

Son olarak öğrenciler kişilik özellikleri bakımından ele alındığında beş faktörlü kişilik özelliklerinden (Dışadönüklük, Yumuşakbaşlılık, Özdenetimlilik, Nörotiklik Deneyime açıklık) yumuşakbaşlılık ve özdenetimlilik alt boyutları ile optimal performans duygu durumu düzeyleri arasında anlamlı doğrusal bir ilişki olduğu tespit edilmiş, öğrencilerin bu alt boyut düzeyleri artış gösterdikçe optimal performans duygu durumları düzeyinin de artış gösterdiği belirlenmiştir. Fullagar ve diğ. (2013)’ne göre pozitif duyguların insanın iç kaynaklarını, becerilerini, zihinsel ve davranışsal işlevlerini güçlendirdiği ve dolayısıyla en optimal düzeyde iş yapabilmesinin önünü açtığı belirlenmiştir.

\section{Makalenin Bilimdeki Konumu}

Müzik Eğitimi ABD,

\section{Makalenin Bilimdeki Özgünlüğü}

Güzel Sanatlar Lisesi müzik öğrencileri için optimal performans duygu durumlarının bu araştırmadaki örneklemle çeşitli değişkenlere göre incelemeye yönelik bir çalışma henüz yapılmamıştır. Yapılan bu araştırma, öğrencinin kendini tanıması, öğreticilere optimal bağlamda performansını yükseltebilmesi yönelik bilgiler sunması bakımından önemli görülmektedir.

\section{Kaynaklar}

Altıntaş A. (2015). Sporcuların Zihinsel Dayanıklılıklarının Belirlenmesinde Optimal Performans Duygu Durumu, Güdülenme Düzeyi ve Hedef Yöneliminin Rolü. (Yayınlanmamış doktora tezi). Ankara Üniversitesi Sağlık Bilimler Enstitüsü, Ankara.

Aşçı F. H., Çağlar E., Eklund R. C., Altıntaş A. ve Jackson S. (2007). Durumluk ve sürekli optimal performans duygu durum-2 ölçekleri'nin uyarlama çalışması. Spor Bilimleri Dergisi. 18 (4), 182-196.

Bakker, A.B. (2005). Flow among music teachers and their students: the crossover peak experiences. Journal of Vocational Behavior. 66, 26-44. 
Baumann, N. (2012). Autotelic personality. Advances in Flow Research, Springer Science Business Media: 155-186.

Büyüköztürk, Ş., Çakmak, E. K., Akgün, Ö. E., Karadeniz, Ş. ve Demirel, F. (2011). Bilimsel araştırma yöntemleri. Ankara. Pegem Yayınevi.

Csikszentmihalyi, M. (2017) Akış Mutluluk Bilimi, Çev. Barış Satılmış, Buzdağı Yayınları: Ankara.

Çetinkalp C.O. (2011). Optimal Performans Duygu Durumu ve Fiziksel Benlik Algısı: Dansçılar Üzerine Bir Çalışma. (Yayınlanmamış Yüksek Lisans Tezi). Ege Üniversitesi Sosyal Bilimler Enstitüsü, İzmir.

Demirutku, K , Ağaoğlu, D . (2018). Tiyatro izleyicisinin akış deneyimi: duygudurumların çeşitliliği, yoğunluğu ve değerliği hipotezlerinin sınanması. Ayna Klinik Psikoloji Dergisi, 5 (3), 33-60 . DOI: 10.31682/ayna.424536

Ertürk, S. (1997). Ĕğitimde Program Geliştirme. Ankara. Meteksan.

Eryılmaz, A. ve Mammadov, M. (2016). Matematik dersinde akış durumu ölçeğinin geliştirilmesi. Ĕgitimde Kuram ve Uygulama, 12 (4), 870-890.

Fidan, N. (1993). Okulda Öğrenme ve Öğretme. Ankara: Alkım yayınevi.

Fraenkel, J.R. \& Wallen, N.E. (2006). How to design and evaluate research in education (Sixth edition). Boston: McGraw-Hill Pub.

Fullagar, C. J., Knight P.A. \& Sovern, H. S. (2013). Challenge/Skill balance, flow and performance anxiety. Applied psychology: An International Review. 62 (2), 236259.

Goldberg, L. R. (1990). An alternative “description of personality”: The Big-Five factor structure. Journal of Personality and Social Psychology. 59, 1216-1229.

Horzum, M. B., Ayas, T. ve Padır, M. A. (2017). Beş faktör kişilik ölçeğinin Türk kültürüne uyarlanmas1. Sakarya University Journal of Education. 7(2), 398-408.

Jackson, S. A. (1996). Toward a conceptual understanding of the flow experience in elite athletes. Research Quarterly for Exercise and Sport. 67(1), 76-90.

Jackson, S. A. ve Marsh, H. W. (1996). Development and validation of a scale to mea-sure optimal experience: The Flow State Scale. Journal of Sport \& Exercise Psychology. 18, 17-35. 
Jackson, S. A. ve Eklund, R. C. (2002). Assessing flow in physical activity: The flow state scale-2 and dispositional flow scale-2. Journal of Sport and Exercise Psychology. 24, 133-150.

John, O. P., Naumann, L. P. ve Soto, C. J. (2008). Paradigm shift to the integrative big-five trait taxonomy: History, measurement and conceptual issues. In O. P. John, R. W. Robins, and L. A. Pervin (Eds.). Handbook of Personality. Theory and Research (pp.114-158), New York, NY: Guilford Press.

Karasar, N. (2006). Bilimsel araştırma yöntemi. Ankara. Nobel Yayınevi.

Kivikangas, J. M. (2006). Psychophysiology of Flow Experience: An Explorative Study. (Master Thesis). Department of Psychology, University of Helsinki.

McCrae, R. R. ve Costa, P. T. (2008). The five-factor theory of personality. In O. P. John, R.W. Robins, \& L. A. Pervin (Eds.), Handbook of personality: Theory and research (3rd ed., pp. 182-207). New York: Guilford Press.

Moneta, G. B. (2004). The flow experience across cultures. Journal of Happiness Studies. 5, 115-121.

O'Neill, S. (1999). Flow theory and the development of musical performance skills. Bulletin of the Council for Research in Music Education. 141, 129-134.

Rammstedt, B.ve John, O. P. (2007). Measuring personality in one minute or less: a 10-item short version of the big five inventory in English and German. Journal of research in Personality. 41(1), 203-212.

Sahranç, Ü. (2013). Bir durumluk akış modeli: stres kontrolü, genel özyeterlik, durumluk kaygı, yaşam doyumu ve akış ilişkileri. Sakarya Üniversitesi Eğitim Fakültesi Dergisi. (16), 122-144.

Sheridan, M., \& Byrne, C. (2002). Ebb and flow of assessment in music. British Journal of Music Education. 19(2), 135-143.

Sönmez, V. (1986). Türkiye'de eğitimin kalitesi ve geleceği. Ankara: Eğitim Fakültesi Dergisi. 1, 49-63.

Sönmez, V. (1994). Eğitim Felsefesi. (üçüncü baskl). Ankara

Türk Dil Kurumu. (2011). Türkçe Sözlük. İstanbul: Türk Dil Kurumu Yayınları.

Temel, A. (2003). Öğrenme isteği nasıl artır1lır. Eğitim ve Bilim Dergisi. 54, 30-31. 
YYÜ Eğitim Fakültesi Dergisi (YYU Journal of Education Faculty), 2020; 17(1):741-767, http://efdergi.yyu.edu.tr ,

Teztel, G. (2016). Psikolojide akış kuramı ve müzik icrası bağlamında değerlendirilmesi. Konservatoryum. 3(2), 1-17.

Yaşin, T. (2016). Kişilik Özellikleri ve Psikolojik Sermayenin Psikolojik İyi Oluş, Akış Deneyimi, İş Tatmini ve Çalışan Performansına Etkileri. (Yayınlanmamış doktora tezi). Başkent Üniversitesi Sosyal Bilimler Enstitüsü, Ankara.

Yılmaz, Z. (2004). Aristoteles’in eğitim anlayışı. Kazım Karabekir Eğitim Fakültesi Dergisi.10, 148-159. 


\section{Summary}

\section{Statement of Problem}

There are many internal and external factors that affect instrument performances as in art, sports or in any performance. Many factors can affect the performance of instruments positively or negatively such as student's age or class representing the age group, gender, physical characteristics, personality traits, instrument, instrument working discipline, instrument working or playing environment, motivation, environmental climatic conditions of the performance environment, and so on.

The musician must be able to immerse himself completely in music without thinking about anything for optimal, in other words, most effective, most appropriate, best instrument performance. He can get satisfaction from his musical performance just in this way. Negative emotions such as anxiety, stress and fatigue during a performance may make it difficult to focus and prevent the desired musical pleasure. These emotions are closely related to the personality traits of the individual.

Although the concept of optimal performance and emotion is generally the subject of studies in the field of sports and exercise in our country, initially we see two academic studies especially in the field of art Çetinkalp 's (2011) master's thesis work, in the field of music Teztel 's (2016) "Psychology flow theory and evaluation in the context of music performance" In our country, the most basic tools in expressing themselves and experiencing flow are the basic tools of Fine Arts High Schools, which constitute the basis of vocational music education and the young musician candidates studying in these schools, and the most basic ways are the performances with their instruments. In order to increase students' instrument performances and enjoy these performances, it has been investigated whether the optimal performance emotions of Fine Arts High School students for their instruments differ according to gender, class level, or occupational characteristics of the students according to various demographic variables.

\section{Purpose of the Study}

The performance of the students of Fine Arts High Schools, which is one of the cornerstones of professional music education, is thought to be developed and increased in the performance of the instrument and the determination of the importance of the emotions and the variables that affect these emotions depending on these performances. For this reason, this study aims to investigate various variables that affect optimal performance emotions for musical instrument performance of Fine Arts High School students. 


\section{Method}

All of the music education students at the Fine Arts High Schools in music departments in Turkey constitute the universe of the research and the sample of the research are randomly determined total (189 girls, 111 boys) ) 300 students, in music education in each class level in 2018-2019 Education Year from Amasya, Çorum, Ordu, Samsun and Tokat High Schools of Fine Arts located in Central Black Sea Region located( Amasya Fine Arts High School, Çorum Fine Arts High School, Ordu Penbe- Izzet Şahin Fine Arts High School, Samsun Ilkadım Fine Arts High School and Tokat Fine Arts High School).

In the study, one personal information form with demographic characteristics and two scales were used as data collection (measurement) tool. The 10-item "Five Factor Personality Scale", which was developed by Rammstedt and John (2007) and adapted to Turkish by Horzum, Ayas and Padir (2017), was used to measure the personality traits of the students participating in the study. In order to measure mood, SOPDÖ-2, State and Continuous Optimal Performance Emotional Status Scales of 36 items and nine sub-dimensions, which were developed by Jackson and Eklund (2002) and adapted to Turkish by Aşçı and the others (2007), were used. The reliability of the Five-Factor Personality Scale and Continuous Optimal Performance Emotion Status 2 used in the study for this study were checked by looking at their reliability (internal consistency) with Alpha Model. In this study, parametric tests, t-test and one-way ANOVA tests were used.

\section{Findings and Discussion}

When the variables affecting the optimal performance emotional states of the Fine Arts High School students for their instrument performances are examined, significant differences and relationships were observed between the average of the students' optimal performance mood levels and how many years they have played their instruments, the number of weekly exercises they have done with their instruments, the level of activity they attended with their instruments, the personal characteristics, mildness and self-efficacy. Besides, significant differences and relationships were found between the sub-dimensions of the optimal performance emotional state and the gender of the students, the types of instruments, the number of years they played their instruments, the number of weekly exercises with their instruments, and the level of activity they participated in with their instruments.

When the instrument types of the students were considered, there was no difference in the general average of the level of optimal performance mood, while it was found that the 
level of the students in the string instruments group aimed at achieving the goal from the subdimensions was higher than the levels of the students in the other two groups. In this respect, it can be mentioned that in Fine Arts High Schools, especially in orchestras, the majority of the group consists of students playing string instruments.

\section{Conclusions and Recommendations}

According to these findings, students who exercise more with their instruments will have higher flow experience, inner satisfaction and pleasure from the time spent with their instruments. It can be said that the more time students spend with their instruments, the more disciplined they work regularly, the more they will develop their skills and the happiness of getting pleasure from this period time. Students get the opportunity to use their skills developed during their work outside the course. In addition, Professor Csikszentmihalyi, who put forward the flow theory in the context of free time about this subject, says "the current resulting from the use of skills leads to improvement" "(Csikszentmihalyi 2017, p.235).

The music department of the high school of fine arts has a very important place in the evaluation of the development of its students in activities such as concerts and competitions which are seen as serious activities in which students exhibit their instruments. In this sense, it is thought that it is very important for the experienced students to gain intense pleasure and inner satisfaction from these activities that they participated with the flow experience instruments.

When the students were considered in terms of personality traits, it was found that there was a significant linear relationship between the five-factor personality traits (Extraversion, Softness, Self-regulation, Neuroticity Experience, and self-regulation subdimensions and optimal performance mood clarity). It has been determined that as these subdimension levels of students increased, the level of optimal performance moods increased. According to Fullagar and the others (2013), it was found that positive emotions strengthened human resources, skills, mental and behavioral functions, and thus paved the way for doing business optimal level. 